\title{
High Temperatures Reduce Postharvest Flowering of Specialty Floral Crop Species
}

\author{
Millie S. Williams, ${ }^{1}$ \\ Terri W. Starman, ${ }^{2}$ and \\ James E. Faust ${ }^{3}$
}

AdDITIONAL INDEX WORDS. heat tolerance, heat stress, Argyranthemum frutescens, Sutera cordata, Brachycome bybrid, marguerite, swan river daisy, bacopa

Summary. The effect of increasing temperatures on the duration of postharvest flower development was determined for three specialty crop species: marguerite (Argyranthemum frutescens Webb ex Schultz-Bip.) 'Butterfly' and 'Sugar Baby'; swan river daisy (Brachycome hybrid Cass.) 'Ultra'; and bacopa (Sutera cordata Roth.) 'Snowflake'. Plants were grown in a greenhouse at $18^{\circ} \mathrm{C}(65$ $\left.{ }^{\circ} \mathrm{F}\right)$ until flowering, and then transferred into a phytotron to determine heat tolerance. Plants were stored for 8 weeks at constant temperatures of $18,23,28$, and $33{ }^{\circ} \mathrm{C}(65,73,82$, and $91{ }^{\circ} \mathrm{F}$ ) for 2 -week intervals. Flower bud and flower number were recorded weekly. Sutera cordata 'Snowflake' and B. hybrid 'Ultra' had the greatest flower number at the $\mathbf{2 3}$ ${ }^{\circ} \mathrm{C}$ temperature, decreasing in the 28 ${ }^{\circ} \mathrm{C}$ environment. Argyranthemum frutescens 'Butterfly' and 'Sugar Baby' had greatest flower number at $28{ }^{\circ} \mathrm{C}$, but flowers were of lower quality than at $23{ }^{\circ} \mathrm{C}$. Flower development of all cultivars ceased at $33{ }^{\circ} \mathrm{C}$, at the end of 8 weeks at increasing temperatures, but when plants were returned to the $18{ }^{\circ} \mathrm{C}$ production greenhouse, flower development resumed. High tempera-

Dept. of Ornamental Horticulture and Landscape Design, Institute of Agriculture, University of Tennessee, Knoxville, TN 37901-1071.

Research conducted at the University of Tennessee, Knoxville, TN. Use of trade names does not imply endorsement of the products named not criticism of similar ones not named. Statistical analysis done by Dr. Arnold Saxton._The cost of publishing this paper was defrayed in part by the payment of page charges. Under postal regulations, this paper therefore must be hereby marked advertisement solely to indicate this fact.

${ }^{1}$ Graduate research assistant.

${ }^{2}$ Associate professor.

${ }^{3}$ Assistant professor. 
tures $\left(28^{\circ} \mathrm{C}\right)$ reduce the postharvest performance of $S$. cordata, B. bybrid, and $A$. frutescens plants grown in hanging baskets; therefore, these species should be marketed as springflowering products since summer performance may be unsatisfactory in warm climates.

$\mathrm{T}$ emperature affects timing of flowering, flower number and flower size in many floral plants. For example, chrysanthemum (Dendranthema grandiflora Tzvelev.) grown in photoinductive short daylengths under $30{ }^{\circ} \mathrm{C}$ day and $26^{\circ} \mathrm{C}$ $\left(86\right.$ and $79^{\circ} \mathrm{F}$ ) night temperatures flowered $12 \mathrm{~d}$ later than plants grown in 22 ${ }^{\circ} \mathrm{C}$ day and $18{ }^{\circ} \mathrm{C}\left(72\right.$ and $\left.65^{\circ} \mathrm{F}\right)$ night temperatures. These plants also developed abnormal inflorescences (Whealy et al., 1987). Centradenia inaequilateralis (Schlechtd. \& Cham.) G. Don 'Cascade' flowered earlier and produced a higher number of visible buds after exposure to 12 or $15^{\circ} \mathrm{C}(54$ or $59{ }^{\circ} \mathrm{F}$ ) for 6 weeks. However, no visible buds were recorded for plants grown at 21 or $24^{\circ} \mathrm{C}\left(70\right.$ or $\left.75^{\circ} \mathrm{F}\right)$ (Friis and Christensen, 1989). The flower number of Impatiens wallerana Hook. F. increased from 24 to 50 and flower size was $33 \%$ smaller as the daytime and night growing temperatures increased from 24 and $18^{\circ} \mathrm{C}\left(75\right.$ and $\left.65^{\circ} \mathrm{F}\right)$ to 35 and $30^{\circ} \mathrm{C}\left(95\right.$ and $\left.86^{\circ} \mathrm{F}\right)$ day and night, respectively (Lee etal., 1990). The flower size of Viola Xwittrockiana Gams. also decreased from $26 \mathrm{~mm}$ (1.0 inch) at 10 ${ }^{\circ} \mathrm{C}\left(50{ }^{\circ} \mathrm{F}\right)$ to $10 \mathrm{~mm}(0.4$ inch $)$ at $25^{\circ} \mathrm{C}$ $\left(77^{\circ} \mathrm{F}\right)$ (Pearson et al., 1995).

Temperatures experienced during summer months in the southern United States can inhibit the flowering of plants as well as alter their development. This can result in decreased consumer satisfaction with plant species that cease flowering throughout the heat of the summer. The objective of this experiment was to characterize the heat tolerance of three specialty floral crop species in order to predict their summer performance in different climatalogical regions of the United States.

\section{Materials and methods}

Plant material. Rooted cuttings of $A$. frutescens 'Butterfly' and 'Sugar Baby'; B. hybrid 'Ultra', and S. cordata 'Snowflake' were acquired from Four Star Greenhouse, Inc., Carleton, Mich., as vegetatively propagated rooted plugs grown in 84 proplug trays (84 plugs/tray). These cultivars were chosen because of their popularity in the industry, their large flower number, and rapid flower development.

Plant production in greenhouse. Plants were transplanted into a soilless medium (Pro-Mix BX, Premier Horticulture, Inc., Red Hill, Pa.) in 10-cmdiameter (4.0-inch) plastic containers on 4 Dec. 1996. Plants were grown in a glass greenhouse at $18{ }^{\circ} \mathrm{C}\left(65^{\circ} \mathrm{F}\right)$ (temperature set point) until they were marketable, i.e., the foliage covered the container and the flowers were distributed evenly across the plant canopy. Plants were fertigated by hand as needed with $15 \mathrm{~N}-6.88 \mathrm{P}-14.11 \mathrm{~K}$ Peter's water-soluble fertilizer (Scotts-
Sierra Horticultural Products Company, Marysville, Ohio) at $200 \mathrm{mg} \cdot \mathrm{L}^{-1}(200$ ppm) N.

Phytotron environment. The phytotron consisted of a $2.4 \times 0.9 \times 1.2 \mathrm{~m}(7.9 \times$ $3.0 \times 3.9 \mathrm{ft}$ ) high polyethylene tent maintained inside of a double-layer polyethylene greenhouse. An 879-W air conditioner unit was placed in the wall of the phytotron and served to

Fig. 1. Effect of temperature on (A) flower number, (B) mature bud number, (C) immature bud number, (D) flower and bud number, and (E) senesced flower number of Argyrantbemum fintescens 'Butterfly.' Error bars represent \pm lsE of the mean. SE bars not visible are smaller than symbol.
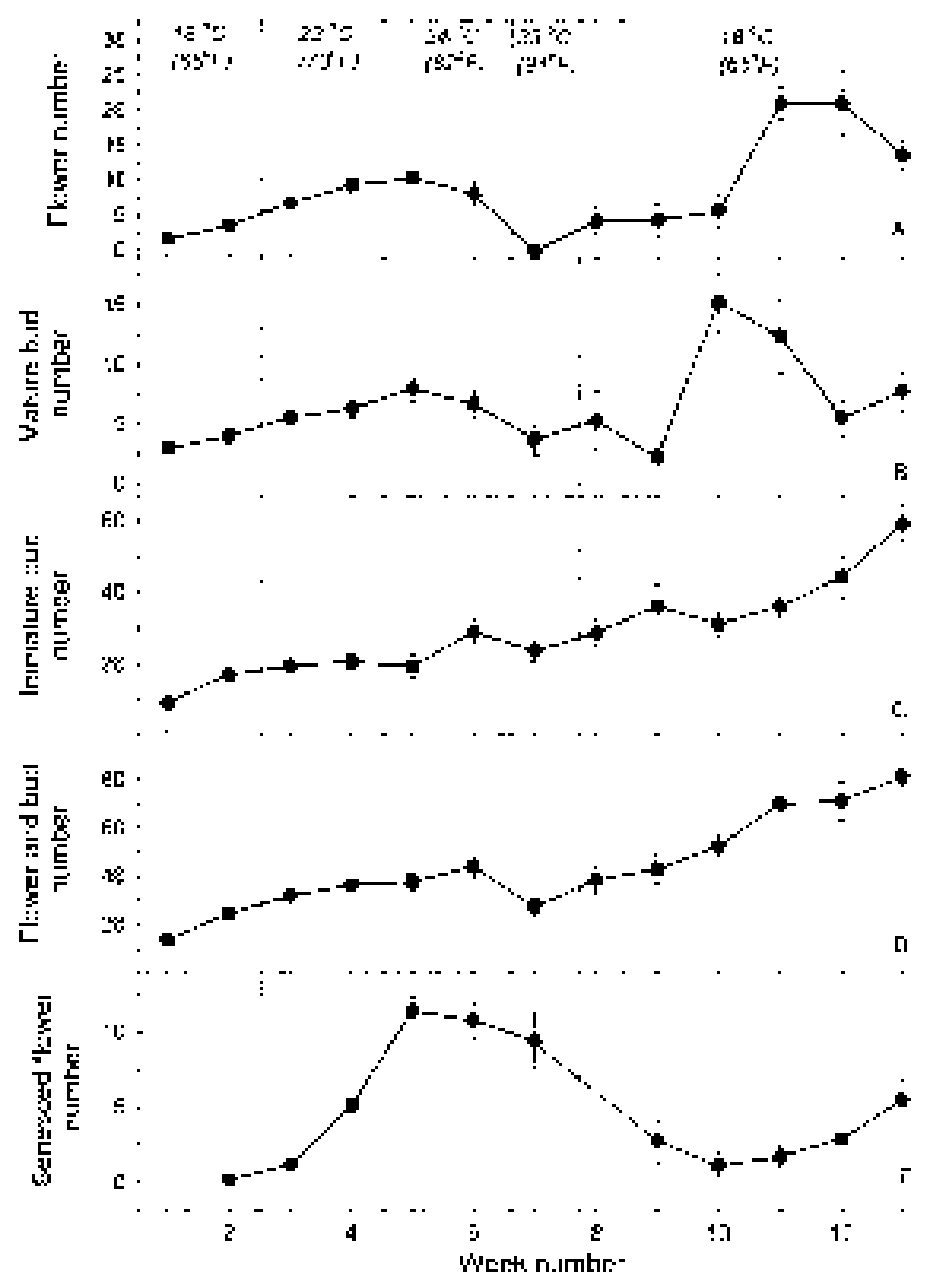


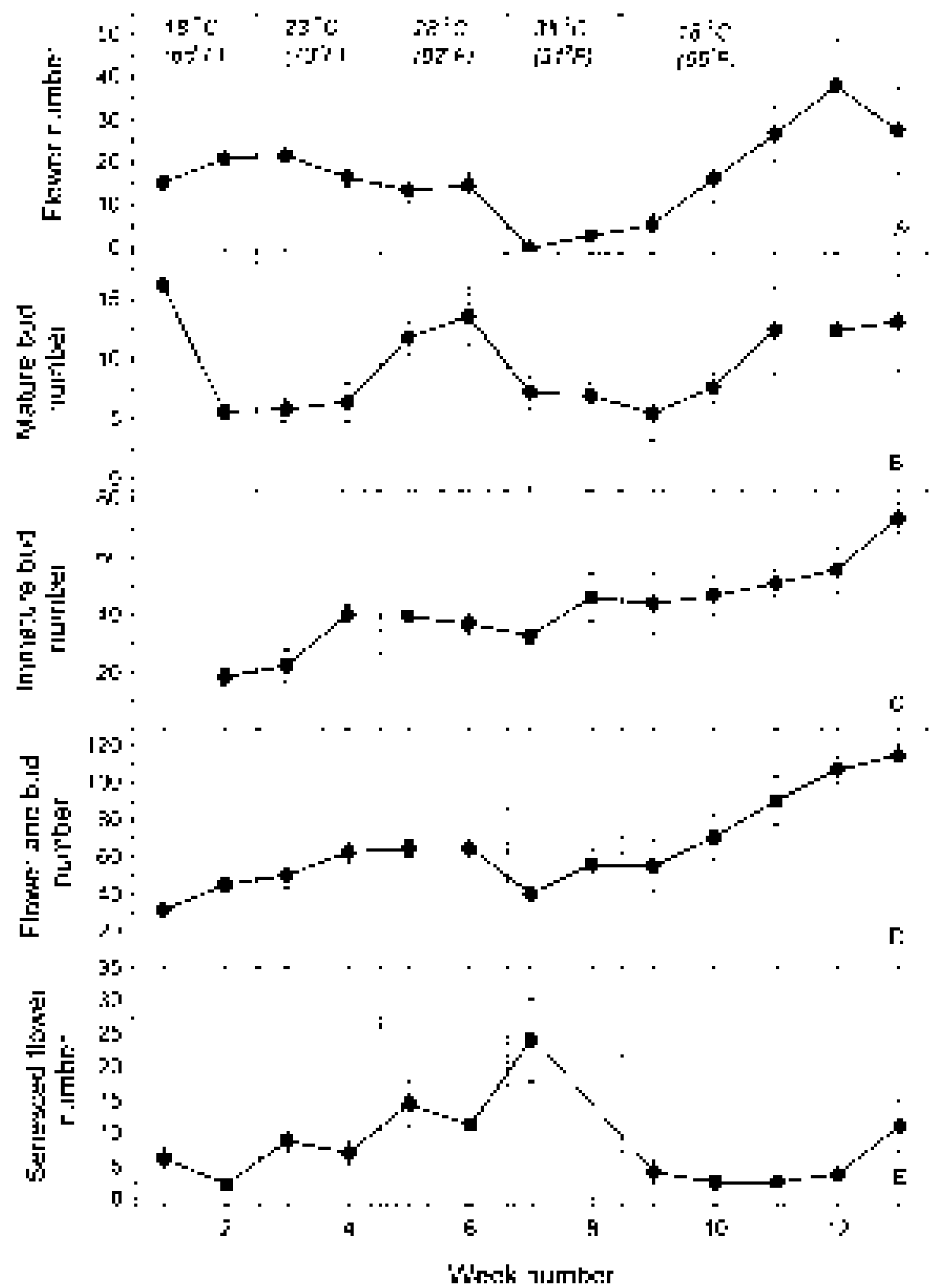

Fig. 2. Effect of temperature on (A) flower number, (B) mature bud number, (C) immature bud number, (D) flower and bud number, and (E) senesced flower number of Argyrantbemum fintescens 'Sugar Baby.' Error bars represent \pm lse of the mean. SE bars not visible are smaller than symbol.

exchange greenhouse and phytotron air. Two small portable space heaters were placed inside the phytotron along with a fan (120V, 1.1 AMP) to provide constant air circulation. Air temperatures inside the phytron were measured with a shaded and aspirated, chromel-constantan thermocouple placed in the center of the phytotron at canopy level. Air temperature measurements were recorded with a datalogger (model 21X; Campbell Scientific, Logan, Utah), once per second, and these measurements were used to control the heater and air conditioner.

Postharvest culture in Phytotron. Plants were fertigated as much as two or three times daily as described for greenhouse production. A moist capillary mat was placed under the pots to aid in maintaining moist media. Plants received ambient sunlight each day and night interruption lighting provided by incandescent bulbs from 10:00 PM until 2:00 AM. Two incandescent 60 watt bulbs were placed $0.5 \mathrm{~m}(20$ inches) above the bench. Night inter- ruption lighting provided a constant long day photoperiod throughout the course of the experiment.

Five plants of each cultivar were placed randomly into the phytotron on 7 Feb. 1997. Heat stress can be caused by day, night, or average daily temperatures; therefore, constant temperatures were provided so that the results would not be complicated by having the day and night temperature different from the average daily temperature. The constant temperature set points were $18,23,28$, and $33{ }^{\circ} \mathrm{C}$ $\left(65,73,82,91^{\circ} \mathrm{F}\right)$. Starting with 18 ${ }^{\circ} \mathrm{C}$, each temperature was delivered for a 2 -week period and then increased serially to the next temperature treatment. After the $33{ }^{\circ} \mathrm{C}$ period, the plants were placed back into the greenhouse at $18{ }^{\circ} \mathrm{C}$ and evaluated for resumption of flowering. Data were analyzed using a one-way linear model (SAS, Cary, N.C.) for each cultivar to test week differences. When significant differences were found, a multiple comparison test was run.

The number of flowers and flower buds were recorded once per week. Flower buds were counted as mature buds (i.e., buds showing flower color) and immature buds (i.e., green buds not showing flower color) present per plant. Flower and bud number was the sum of all flowers, colored and green buds present. The total number of senescing flowers per plant were also counted each week. Due to the numerous flower buds on S. cordata and difficulty in locating senesced flowers, immature bud number and senescing flower number were not measured.

\section{Results and discussion}

Argyranthemum frutescens 'BUTTERFLY'. Flower number was greatest at $23{ }^{\circ} \mathrm{C}$ and $28{ }^{\circ} \mathrm{C}\left(73\right.$ and $\left.82{ }^{\circ} \mathrm{F}\right)$ temperatures. However, during the second week at the $28^{\circ} \mathrm{C}$ temperature, flower number began to decrease. There were eight flowers in the second week at 23 ${ }^{\circ} \mathrm{C}$ and nine in the first week at $28^{\circ} \mathrm{C}$, decreasing to zero at $33{ }^{\circ} \mathrm{C}\left(91{ }^{\circ} \mathrm{F}\right)$ temperature (Fig. 1A). In the $28{ }^{\circ} \mathrm{C}$ treatment flowers were smaller and senescing around the flower petal margins. The mature bud number decreased from eight in the $28^{\circ} \mathrm{C}$ to four in the $33^{\circ} \mathrm{C}$, where several buds were aborted (Fig. 1B). The immature bud number was influenced by temperature, reaching a maximum of 29 in the second week of $28{ }^{\circ} \mathrm{C}$ treatment, de- 


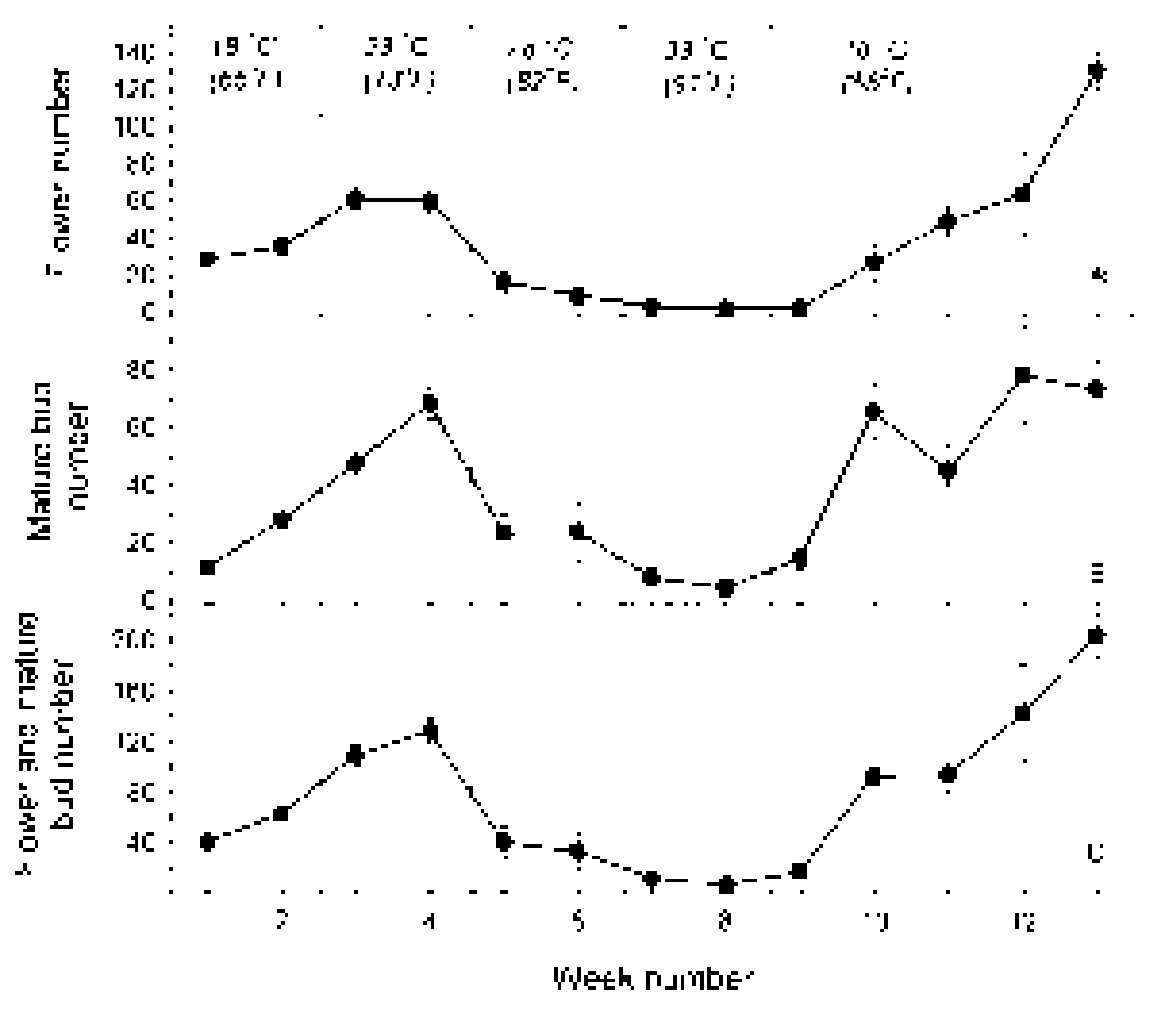

Fig. 3. Effect of temperature on (A) flower number, (B) mature bud number, and $(C)$ flower and mature bud number of Sutera cordata 'Snowflake.' Error bars represent \pm lsE of the mean. SE bars not visible are smaller than symbol.

creasing slightly to 24 buds in the 33 ${ }^{\circ} \mathrm{C}$ (Fig. 1C). Flower and bud number was highest in the $28{ }^{\circ} \mathrm{C}$ treatments (Fig. 1D). The number of senesced flowers increased from zero and five in $18\left(65^{\circ} \mathrm{F}\right)$ and $23{ }^{\circ} \mathrm{C}$ to 11 and 9 senesced flowers in the 28 and $33^{\circ} \mathrm{C}$, respectively (Fig. 1E). The optimum temperature for flower development of $A$. frutescens 'Butterfly' was at 23 and $28{ }^{\circ} \mathrm{C}$, with $28{ }^{\circ} \mathrm{C}$ resulting in lowered flower size and quality. In the second week of the $28^{\circ} \mathrm{C}$ treatment, immature bud number continued to increase, however, the flower and mature bud number was not increasing. Therefore, the $28{ }^{\circ} \mathrm{C}$ treatment allowed bud development, but not flower development. After 1 week in $33{ }^{\circ} \mathrm{C}$ plants ceased flowering, so, they were placed back into the $18{ }^{\circ} \mathrm{C}$ environment, and flower development resumed.

Argyranthemum frutescens 'SUGAR BABY'. Flower number decreased from 19 in the first week at $23{ }^{\circ} \mathrm{C}$ to 14 in the 28 ${ }^{\circ} \mathrm{C}$ (Fig. 2A). Flowers were observed to be necrotic around the petal mar- gins and narrower in diameter in the $28{ }^{\circ} \mathrm{C}$ treatment. Flower number decreased to zero in the $33^{\circ} \mathrm{C}$ temperature. Mature bud number increased at $28^{\circ} \mathrm{C}$ then was reduced due to aborted buds. Plants in the $28^{\circ} \mathrm{C}$ temperature had 13 mature buds, and in the next week with a temperature increase to $33^{\circ} \mathrm{C}$, no flowers developed from the buds and the mature bud number decreased to seven (Fig. 2B). When plants had been back in the $18{ }^{\circ} \mathrm{C}$ environment for 2 weeks, flower development resumed. The immature bud number was highest in the $33{ }^{\circ} \mathrm{C}$ treatment, reaching 46 (Fig. 2C); however, the flower buds were not developing into flowers at this temperature (Fig. 2A). Senesced flower number increased in the $33{ }^{\circ} \mathrm{C}$ treatment. There were 13 senesced flowers in the $28{ }^{\circ} \mathrm{C}$ treatment, increasing to 24 in the $33{ }^{\circ} \mathrm{C}$ (Fig. 2E). The optimum temperature for flower development occurred between 23 and $28^{\circ} \mathrm{C}$, with flower quality lowered in the $28{ }^{\circ} \mathrm{C}$. Flower and bud number were increased in the 28 ${ }^{\circ} \mathrm{C}$ temperature, however, the number of senesced flowers also increased and subsequent development into open flowers ceased.

Sutera cordata'sNOWFLAKE'. Flower number increased from 32 after 2 weeks in $18^{\circ} \mathrm{C}$ to 61 in $23^{\circ} \mathrm{C}$ treatments, then decreased to 13 in the $28^{\circ} \mathrm{C}$ treatment (Fig. 3A). Not only did flower number decrease in the $28{ }^{\circ} \mathrm{C}$ temperature, flowers were smaller and buds aborted. Mature bud number decreased from 58 after 2 weeks at $23^{\circ} \mathrm{C}$ to 24 in the $28^{\circ} \mathrm{C}$ (Fig. 3B), resulting in reduced flower number at the $28{ }^{\circ} \mathrm{C}$ temperature (Fig. 3A). Total flower and bud number was greatest at $23{ }^{\circ} \mathrm{C}$ temperature, with 52 flowers and 119 mature buds (Fig. 3C). Two weeks after $S$. cordata was placed back into a $18{ }^{\circ} \mathrm{C}$ environment, flowering resumed.

Brachycome hybrid 'Ultra'. Flower number was highest in the $18{ }^{\circ} \mathrm{C}$ temperature. There were 14 flowers after 2 weeks at $18{ }^{\circ} \mathrm{C}$ and 11 at $23{ }^{\circ} \mathrm{C}$, decreasing to 6 at $28^{\circ} \mathrm{C}$ (Fig. $\left.4 \mathrm{~A}\right)$. Not only was flower number decreased at $28^{\circ} \mathrm{C}$, flower quality was also lowered, and flower size was smaller in diameter and faded in color. Mature bud number decreased from 13 in the $28^{\circ} \mathrm{C}$ to 5 in the $33{ }^{\circ} \mathrm{C}$ treatments (Fig. 4B). Mature bud number decreased at 28 ${ }^{\circ} \mathrm{C}$ with no increase in flower number. Immature buds increased from 29 at $23{ }^{\circ} \mathrm{C}$ to 46 at $28^{\circ} \mathrm{C}$, and then decreased to 34 at $33{ }^{\circ} \mathrm{C}$ (Fig. 4C). Flower and bud number decreased to 40 in the $33{ }^{\circ} \mathrm{C}$ temperature, from 61 in the $28{ }^{\circ} \mathrm{C}$ treatment (Fig. 4D). Since flowers were smaller in size and faded in color in the $28{ }^{\circ} \mathrm{C}$, we concluded the optimum temperature environment for flower development to be between 18 and $23^{\circ} \mathrm{C}$. Brachycome hybrid began to flower 2 weeks after being placed back into an $18{ }^{\circ} \mathrm{C}$ environment.

\section{Conclusion}

This study allowed us to estimate how well these species will perform in different climates. For example, according to normal average daily temperatures, A. frutescens 'Butterfly' and 'Sugar Baby' would flower best until mid-June, reflowering at the beginning of August in Knoxville, Tenn., when the average daily temperature is below $28^{\circ} \mathrm{C}\left(82^{\circ} \mathrm{F}\right)$. However, flowers on these plants would last all summer in Buffalo, N.Y., where the average daily temperature does not get above $26^{\circ} \mathrm{C}\left(79^{\circ} \mathrm{F}\right)$. Sutera cordata and $B$. hybrid are spring crops flowering from mid-April until mid-May in Knoxville, Tenn.; however, they would flower until June in Buffalo, N.Y., when average daily temperatures are below $23^{\circ} \mathrm{C}\left(73^{\circ} \mathrm{F}\right)$. Growing these plants further south in Albany, Geor- 
Fig. 4. Effect of temperature on (A) flower number, (B) mature bud number, (C) immature bud number, (D) flower and bud number, and (E) senesced flower number of Brachycome bybrid 'Ultra.' Error bars represent \pm l SE of the mean. SE bars not visible are smaller than symbol.

gia, would result in $S$. cordata and $B$. bybrid flowering until the end of April; while, A. frutescens 'Butterfly' and 'Sugar Baby' would flower until May.

Commercial greenhouse growers could use this information to determine whether to grow these crops as spring holiday crops or for the summer gardening market. Consumers expect garden crops to continue to bloom throughout the summer months. Spring holiday crops are purchased mostly as gifts and must look good for the holiday, but long-term performance is not always necessary. This information is also beneficial for grow-

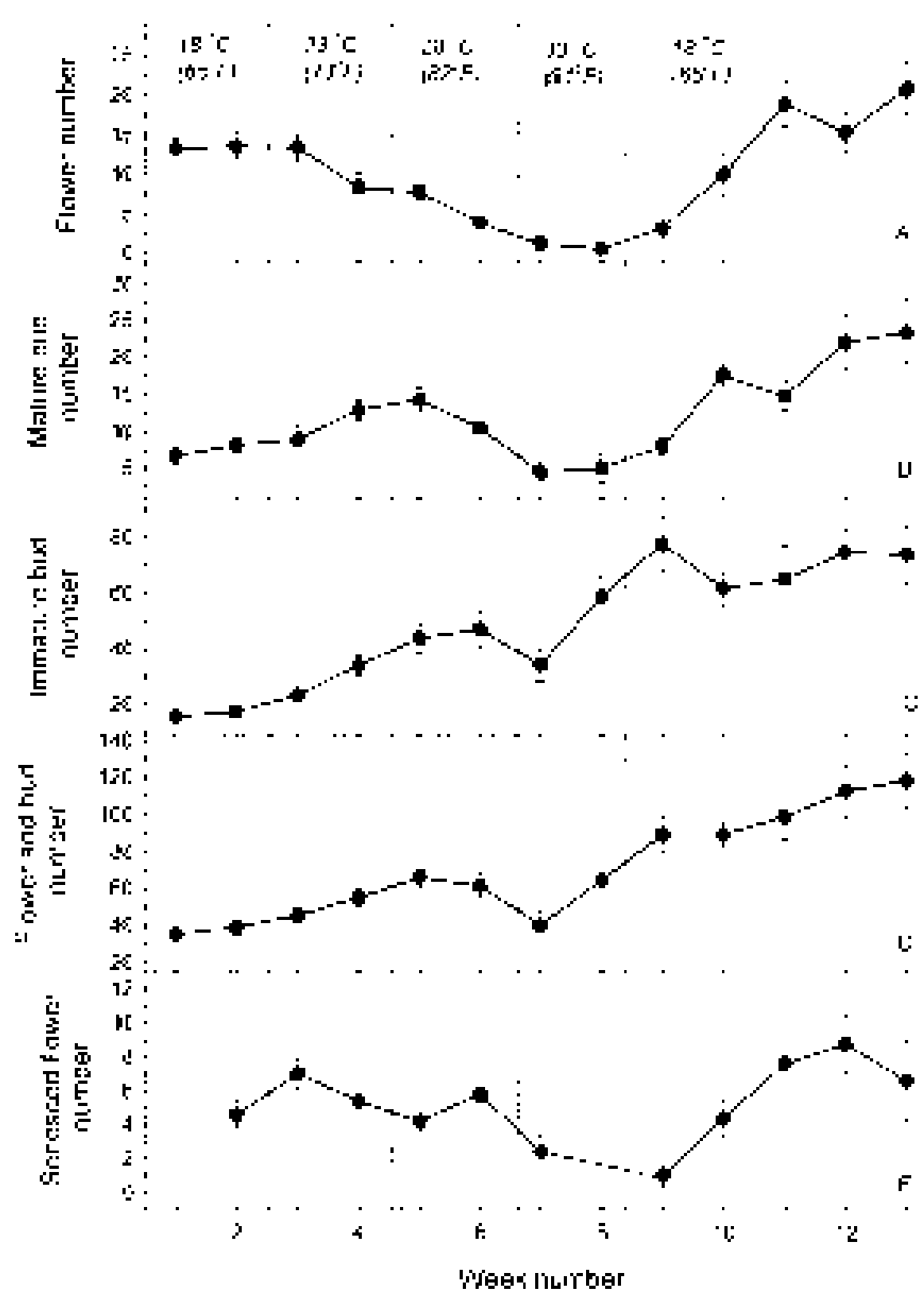

ers and retailers when putting plants together in container gardens. They want to use plants that have similar temperature requirements in the same container so that all the plants will be in bloom at the same time. Landscapers in southern states would want to use these species in spring plantings, knowing they would need to replace them with more heat-tolerant crops later in the growing season.

\section{Literature cited}

Lee, W.S., J.E. Barrett, and T.A. Nell. 1990. High temperature effects on the growth and flowering of Impatiens wallerana cultivars. Acta Hort. 272:121127.

Pearson, S., A. Parker, S.R. Adams, P. Hadley, and D.R. May. 1995. The effects of temperature on the flower size of pansy. J. Hort. Sci. 70:183-190.

Whealy, C.A., T.A. Nell, and J.E. Barrett. 1987. High temperature effects on growth and floral development of chrysanthemum. J. Amer. Hort. Sci. 112:464-468.
Friis, K. and O.V. Christensen. 1989. Flowering of Centradenia inaequilateralis ' ${ }^{\mathrm{C}} \mathrm{Ca}-$ cade' as influenced by temperature and photoperiod. Scientia Hort. 41:125-130. 